\title{
FAMÍLIA E TRABALHO: DIFÍCIL CONCILIAÇÃO PARA MÃES TRABALHADORAS DE BAIXA RENDA
}

\section{MARIA CRISTINA A. BRUSCHINI}

Pesquisadora do Departamento de Pesquisas Educacionais da Fundação Carlos Chagas cbrusch@fcc.org.br

\section{ARLENE MARTINEZ RICOLDI}

Doutoranda em Sociologia pela Universidade de São Paulo aricoldi@uol.com.br

\section{RESUMO}

Este artigo é produto da pesquisa Articulação Trabalho e Família: Famílias Urbanas de Baixa Renda e Políticas de Apoio às Trabalhadoras, que teve por objetivo analisar a administração das dificuldades e dos conflitos que surgem na vida cotidiana de mulheres que trabalham fora de casa e têm responsabilidades familiares. Apresenta dados quantitativos e qualitativos: os primeiros foram extraídos da Pesquisa Nacional por Amostragem de Domicílios, de 2002, e os segundos, da realização de quatro grupos focais, com mulheres de 20 a 45 anos, de famílias de baixa renda, com filhos de até 14 anos. A análise foi realizada de forma integrada, estruturada em torno das seguintes questões: o conceito de trabalho doméstico; a divisão sexual do trabalho doméstico; o uso do tempo em afazeres domésticos; a conciliação do trabalho com a família e políticas sociais que contribuem para essa conciliação.

DIVISÃO SEXUAL DO TRABALHO - MULHERES - FAMILLIAS - POLITICAS SOCIAIS

\section{ABSTRACT}

FAMILY AND WORK: HARD RECONCILIATION FOR LOW-INCOME WORKING MOTHERS. This article results from the research Reconciling Work and Family: Urban Low-Income Families and Policies of Support to Female Workers, the purpose of which was to analyze the management of the obstacles and conflicts that arise in the daily life of women who have family responsibilities and jobs. It provides quantitative and qualitative data: the first were obtained from the National Research by Home Sampling, in 2002, and the second resulted from four focal groups with lowincome women aged 20-45 years old rother of children up to 14 years of age. The analysis was based on the following issues: the concept of domestic work; the sexual division of domestic work; the time used for domestic work; reconciliation of work and family and social policies favoring this conciliation.

SEXUAL DIVISION OF LABOR - WOMEN - FAMILIES - SOCIAL POLICIES

O artigo contou com a colaboração de Cristiano Miglioranza Mercado na confecção das tabelas. 
Este artigo é produto da pesquisa Articulação Trabalho e Família: Famílias Urbanas de Baixa Renda e Políticas de Apoio às Trabalhadoras, que tem por objetivo analisar a administração das dificuldades e dos conflitos que surgem na vida cotidiana de mulheres que trabalham fora de casa e têm responsabilidades familiares. A pesquisa' focalizou famílias de renda inferior a 5 salários mínimos, com domicílio na região da Grande São Paulo e, nelas, as dificuldades das muIheres trabalhadoras, uma vez que são elas as principais responsáveis pelos cuidados com o espaço doméstico e familiar. Ademais, estatísticas recentes sobre a inserção das mulheres no mercado de trabalho têm mostrado que são mulheres mais velhas, casadas e com filhos pequenos aquelas que mais têm adentrado o mercado de trabalho e nele permanecido (Bruschini, Lombardi, 2003).

Os dados utilizados para a etapa quantitativa da pesquisa foram extraídos da Pesquisa Nacional por Amostragem de Domicílios - PNAD (FIBGE, 2002), e, em maior profundidade, dos quesitos "cuidou de afazeres domésticos na semana anterior?", introduzido no questionário da PNAD 1992 (FIBGE, 1993), e "quantas horas gastou na realização de afazeres domésticos?", introduzido no questionário da PNAD 200 I (FIBGE, 2002), para aqueles/as que responderam "sim" à pergunta anterior.

O escopo da pesquisa qualitativa, composta basicamente de debates conduzidos segundo a metodologia de grupos focais ${ }^{2}$, foi limitado a trabalhadoras com filhos menores de 14 anos, em famílias nucleares e em monoparentais chefiadas por mulheres.

Quatro grupos foram constituídos por mulheres com idades entre 20 e 45 anos, exercendo algum tipo de trabalho remunerado, com ou sem carteira assinada. Todas as participantes tinham filhos menores de 14 anos, escolaridade mínima de primário incompleto e máxima de ensino médio completo (excluídas as analfabetas e aquelas com nível superior completo). Em todos os grupos foi mantida a diversidade racial, sendo formados por brancas, pretas e pardas.

I. O relatório completo da pesquisa, que contou com o apoio do Conselho Nacional de Desenvolvimento Científico e Tecnológico - CNPq - e foi realizada em 3 etapas não sequenciais (documental, quantitativa e qualitativa), foi publicado na série Textos FCC, e pode ser consultado no site da Fundação Carlos Chagas (www.fcc.org.br).

2. A técnica do grupo focal é derivada das técnicas de trabalho em grupo desenvolvidas pela Psicologia Social. Supõe a seleção de participantes com algumas características comuns para a realização de uma discussão focalizada, isto é, envolve uma atividade coletiva de discussão com base em uma vivência comum (Gatti, 2005). 
Família e trabalho...

O Grupo I, denominado ${ }^{3}$ Chefes mais jovens, foi constituído por mulheres chefes de família (vivendo sem companheiro), na faixa de 20 a 35 anos, com algum filho menor de 7 anos; o Grupo 2, Chefes mais velhas, constituiu-se de mulheres chefes de família (vivendo sem companheiro), na faixa de 35 a 45 anos, com algum filho entre 8 e 14 anos; o Grupo 3, Cônjuges mais jovens, foi constituído por mulheres de 20 a 35 anos, vivendo com companheiro, com algum filho menor de 7 anos; e, por fim, o Grupo 4, de Cônjuges mais velhas, constituído por mulheres de 35 a 45 anos, vivendo com companheiro, com algum filho entre 8 e 14 anos.

Os dados obtidos por meio da técnica do grupo focal têm limites em relação à sua generalização, mas permitem iluminar aspectos cotidianos em relação a uma configuração macro, como é o caso dos dados da PNAD/IBGE. A técnica atende, portanto, à complementação de uma análise quantitativa, com vivências, experiências e opiniões das participantes sobre a conciliação entre o mundo do trabalho e da família.

Os resultados da análise desses dois conjuntos de dados são apresentados de forma integrada, tendo sido estruturados em torno das seguintes questões: o conceito de trabalho doméstico; a divisão sexual do trabalho doméstico; o uso do tempo em afazeres domésticos; a conciliação do trabalho com a família e políticas sociais que contribuem para a conciliação do trabalho com a família.

\section{O CONCEITO DE “AFAZERES DOMÉSTICOS”}

Qualquer pesquisa que tenha como objeto a vida familiar cotidiana deve remeter, necessariamente, ao trabalho doméstico. Esse conjunto de atividades aparentemente óbvias e sem muita importância e sempre identificadas como atributo essencial das mulheres, só nas últimas décadas começou a ser percebido como indispensável para o bem-estar dos indivíduos que fazem parte da família. Não são poucos os estudos que têm mostrado a universalidade e a persistência de uma divisão sexual do trabalho, que atribui aos homens principalmente as atividades de caráter produtivo, geradoras de renda e desenvolvidas no espaço público, e às mulheres as tarefas reprodutivas, por elas entendendo-se tanto os

3. A partir deste ponto, utilizaremos tais denominações para nos referirmos aos diferentes grupos formados, a fim de facilitar a leitura. 
cuidados com o bem-estar físico e emocional dos membros da família - incluindo alimentação, limpeza, vestuário, higiene pessoal e saúde física e mental - quanto aos cuidados com a própria moradia e com a criação e educação dos filhos.

Ao longo do tempo produziu-se, como resultado dos debates empreendidos pelos estudos sobre o trabalho feminino e o trabalho doméstico, um consenso sobre a importância deste último para a reprodução social, fato que, se não era explicitamente negado, ao menos era omitido. $\bigcirc$ que guiava esses trabalhos era o questionamento sobre a atribuição feminina exclusiva no que diz respeito ao trabalho doméstico, e os processos por meio dos quais se criaram, a partir de um fato biológico: a maternidade, vínculos imediatos e diretos da mulher com as atividades reprodutivas, de tal forma que tais atividades ultrapassam em muito as funções diretamente ligadas ao parto, aleitamento e primeiros cuidados com os nascidos, passando a englobar todo o trabalho doméstico. Hoje é possível afirmar que qualquer análise sobre o trabalho feminino, procurando romper velhas dicotomias, estará atenta à articulação entre produção e reprodução, assim como às relações sociais de gênero.

Ao longo dos anos de 1970 e 1980, ocorreu, concomitantemente, um processo de desvendamento e de crítica às estatísticas oficiais disponíveis para pesquisar a atividade econômica feminina, consideradas inadequadas para mostrar a real contribuição das mulheres à sociedade. Nos levantamentos censitários, a categoria "inativos" abriga indivíduos que não trabalham, seja porque vivem de renda, seja porque são aposentados, pensionistas, doentes ou inválidos, estudantes e os/as que se dedicam exclusivamente aos afazeres domésticos. Ou seja, apesar do considerável número de mulheres de todas as camadas sociais que o realizam, o trabalho doméstico não era, até recentemente, contabilizado como atividade econômica nesse tipo de levantamento.

No caso da PNAD, em particular, procurando incorporar as críticas dos/as estudiosos/as, assim como as demandas dos movimentos sociais, este levantamento, nos anos de 1990, passou por uma profunda reformulação, que teve por objetivo captar uma nova e complexa dinâmica socioeconômica que vinha se forjando desde o início da década de 1980. As principais alterações ocorreram em relação ao conceito de trabalho e desemprego ${ }^{4}$.

4. Para um aprofundamento sobre a reformulação da PNAD e seu conceito de trabalho, ver Bruschini, 2006. 
Família e trabalho...

Na revisão da PNAD/IBGE, em 1990, foi incorporada também a definição de afazeres domésticos, que até então era um quesito específico aplicado somente à parcela inativa da população. Essa definição ${ }^{5}$ contemplou o intenso debate que se travou a respeito da importância do trabalho doméstico, de sua mensuração e consequente "visibilização", sendo considerada um grande avanço das estatísticas oficiais. No entanto, o conceito ainda tem lacunas, como por exemplo, não incluir o cuidado de pessoas idosas e incapazes adultos.

Em trabalho anterior, adotou-se uma ampla definição de trabalho doméstico, com atividades agrupadas em "blocos" (porém, sem intenção de propor uma classificação ou hierarquia):

I. tarefas relativas aos cuidados com a moradia, espaço no qual se passa a vida familiar cotidiana;

2. tarefas de alimentação e higiene pessoal, como cozinhar, lavar pratos e outros utensílios, costurar, lavar e passar roupas;

3. prestação de serviços físicos e psicológicos aos membros das famílias, assim como o cuidado com as crianças, os idosos e os incapacitados da família;

4. administração da unidade doméstica, com atividades que vão desde o pagamento de contas até a administração do patrimônio, bem como a aquisição dos bens de consumo necessários para a casa e a família;

5. manutenção da rede de parentesco e de amizade, que reforçam laços de solidariedade e de convivência.

As atividades elencadas, apesar de serem consideradas como "domésticas", voltadas para a casa, a família ou a rede mais ampla de parentesco, são afazeres que têm diferentes significados e prestígio diverso. Cuidar dos filhos é uma atividade mais valorizada do que limpar a casa, sobretudo na sociedade ocidental moderna, na qual a ideologia da maternidade e, mais recentemente,

5. A definição, que é colocada em prática na PNAD desde 1992, assim resume as atividades que compõem os afazeres domésticos: "arrumar ou limpar toda ou parte da moradia; cozinhar ou preparar alimentos, passar roupa, lavar roupa ou louça, utilizando, ou não aparelhos eletrodomésticos para executar estas tarefas para si ou para outro(s) morador(es); orientar ou dirigir trabalhadores domésticos na execução das tarefas domésticas; cuidar de filhos ou menores moradores" (FIBGE, 1992). 
da paternidade "assumida" (Unbehaum, 2000) tem enfatizado a importância dos papéis materno e paterno para a educação infantil. Cozinhar pode ser uma atividade bastante criativa, enquanto passar roupa raramente o é, e assim por diante. O nível de conhecimento e especialização requerido também varia de uma tarefa para outra. O cuidado com roupas mais sofisticadas, por exemplo, bem como a aquisição da infinidade de pequenos itens solicitados pelos membros da família requerem um razoável nível de especialização e conhecimento por parte de quem o executa. Se uma boa parte dessas atividades são manuais, como fazer camas ou limpar legumes, outra, tem um caráter afetivo, como acompanhar as crianças nas tarefas escolares ou assistir os doentes, ou ainda um caráter intelectual, como é o caso da administração financeira do domicílio. Há também os afazeres que são necessários à organização interna da casa, mas são realizados fora dela, como ir às compras, ao banco, ou levar os filhos ao colégio. $O$ agrupamento dessas atividades em blocos não significa que elas não perpassem outras atividades de outro bloco. A alimentação, por exemplo, pode ser também uma atividade pela qual se estabelece o relacionamento afetivo entre as pessoas da família ou um bom pretexto para aproveitar os momentos de lazer e estreitar laços de convivência entre amigos ou parentes.

Este artigo discute, portanto, como esses processos ocorrem, e porque a maioria das mulheres ainda é a principal responsável pela organização doméstica, se não diretamente, ao menos delegando e distribuindo funções, bem como cobrando resultados.

Entre as participantes dos grupos focais realizados, a noção de afazeres domésticos é uma das questões mais homogêneas encontradas nas discussões, e vai ao encontro das noções descritas. As tarefas elencadas por elas são recorrentes e envolvem quase sempre a ideia do cuidado: cuidar da casa, do marido, dos filhos e de outras pessoas que o necessitem (como idosos e deficientes na família). Quando mencionam em detalhe esses cuidados, verifica-se que eles se compõem de uma série de tarefas: o cuidado da casa envolve, por exemplo, limpeza, arrumação e administração do espaço doméstico, tanto no sentido da administração financeira do domicílio, como na execução e distribuição de tarefas. A tarefa de delegação desses afazeres a terceiros, como empregada, diarista e/ou babá, ou mesmo a vizinhas e/ou parentes que auxiliam nessas funções aparece ao longo dos debates, nas falas das participantes, quase sempre como de sua responsabilidade, ou de outra mulher da família. 
Família e trabalho...

Os filhos são uma parte importante dessas tarefas, e a rotina das mães é particularmente organizada em razão deles, principalmente quando são pequenos: o dia começa muito cedo, com a arrumação da mochila, vestimenta, alimentação e banho para que as crianças possam ser deixadas na creche ou escolinha. Também envolve, no fim do dia, tarefas como lavar, passar e cozinhar, especialmente a tarefa do jantar, uma vez que muitas mães passam o dia inteiro fora de casa, sendo o almoço providenciado por terceiros. Além das tarefas, o cuidado também inclui educar/orientar, acompanhar o desenvolvimento escolar (ver cadernos, lição de casa, participar de reuniões, conversar com professores), dar atenção, conversar, enfim, passar algum tempo com os filhos (o que poderia ser interpretado também como uma prestação de atenção psicológica).

No grupo de Cônjuges mais velhas não houve consenso em relação à concepção de afazeres domésticos, o que é elucidativo do que essas participantes consideram o papel feminino na sociedade e na família. Uma participante, que afirmava ter uma divisão bastante igualitária das tarefas domésticas em casa, disse que havia deixado um bom emprego para cuidar de um dos filhos que nascera prematuro e toma a palavra ao final da discussão: "Eu posso falar uma coisa? Não é que eu seja a semente da discórdia [...] Eu quero saber por que as demais colegas acham que cuidar do marido e filhos são deveres domésticos?" (35 anos, casada, copeira de buffet, 2 filhos). Essa participante tinha uma visão diferenciada a respeito da "maternagem"6: "[...] eu não comparo cuidar dos meus filhos e marido com lavar roupa, passar roupa e arrumar a casa. Eu acho que cuidar deles, sair com eles, passear, assistir televisão juntos faz parte... se fosse um dever doméstico, eu não teria casado e tido filhos". Essa observação encontra eco no que diz Sorj, segundo a qual "esta esfera (doméstica...), mais do que qualquer outra, realiza o valor cultural de que o principal compromisso das mulheres é com a família" (2004a, p. 108).

De fato, para algumas mulheres, os cuidados relativos à maternagem e ao marido são resultado natural do afeto que os ligam, não podendo ser consideradas "tarefas domésticas". Essa leitura parece ter clara a separação entre casa e família, isto é, os cuidados com a primeira são atribuição de todos/as,

6. Termo cunhado por Chodorow (1978) para se referir à dimensão social da maternidade, isto é, aos cuidados com os filhos (educação, alimentação, saúde etc.), cuja responsabilidade social caberia à mãe (biológica ou não). 
enquanto o cuidado psicológico (dar atenção, conversar, passar tempo juntos etc.) faz parte do seu "dia a dia como esposa".

Note-se que o comentário da participante fala em "deveres", mas a pergunta que desencadeou a discussão mencionava "afazeres". Seguiu-se então uma discussão transformando "afazeres" em "deveres", na qual se misturou a questão da obrigação, do dever e do papel feminino nos afazeres domésticos. Essa posição tradicional persistiu no discurso e na prática da maioria das participantes, que afirmaram o caráter obrigatório do trabalho doméstico, às vezes com ressalvas: "Não deixa de ser uma obrigação da gente, mas a gente tem o prazer de fazer" (38 anos, casada, agente de apoio escolar, 3 filhos); Para justificar, por um lado, o caráter obrigatório e, por outro, a maior responsabilidade no cuidado e na educação dos filhos, as participantes recorrem às vezes à ideia da "inabilidade natural masculina" para esses assuntos: "O marido fala 'eu vou ajudar em casa' mas ele não faz igual à mulher" (36 anos, casada, doméstica, 2 filhos).

Desse modo, quando casadas, os cuidados despendidos pelas mulheres aos filhos estendem-se ao marido. Mesmo quando trabalham fora, ainda cuidam da roupa do companheiro, lavam, passam e algumas até escolhem o que ele irá vestir, além de deixar alimentação pronta para o consumo (apesar de comentarem uma participação masculina importante neste quesito).

As Cônjuges mais velhas são as que dão maior ênfase ao cuidado que o marido requer, muitas vezes no sentido da atenção psicológica, como algumas entrevistadas ressaltam: "A gente não cuida só da casa, a gente cuida do marido também. O meu está lá, eu tenho que cuidar [...] ele quer que converse com ele, pelo menos 15 minutos. Seu eu virar do lado e não conversar com ele, no dia seguinte ele está com bico" (35 anos, casada, auxiliar administrativa, I filho).

Coincidentemente, as mulheres do grupo chefes de família mais velhas, no qual muitas já foram casadas, também ressaltam o cuidado dispensado ao ex-cônjuge. Algumas até apontaram uma diminuição importante das tarefas domésticas depois da separação conjugal: "Agora sobra tempo, quando eu tinha marido eu não conseguia fazer nada [...] Ele sujava muita roupa, não tirava o prato do lugar, eu tinha que fazer muito mais comida [...] Depois que ele saiu de casa o serviço reduziu em 50\%" (40 anos, vendedora autônoma, 2 filhas). Muitas integrantes concordaram com a afirmação, endossando também a rejeição a uma nova união com coabitação. 
Família e trabalho...

A administração da unidade doméstica, como pagar contas e tomar decisões sobre o orçamento doméstico, só não foi citada pelas participantes do grupo de cônjuges mais velhas. Isso poderia ser justificado em virtude da presença de uma relação conjugal mais assimétrica sobretudo no grupo das casadas mais velhas, entre as quais, tendo em vista a presença de um companheiro, ficaria a cargo dele a decisão sobre os gastos do domicílio.

\section{A DIVISÃO SEXUAL E ETÁRIA DO TRABALHO DOMÉSTICO}

Neste segundo tópico nos debates, foram abordadas questões relativas ao cotidiano doméstico das trabalhadoras, mediante perguntas como "Quem cuida dessas tarefas na casa de vocês? Os companheiros participam? Em que tarefas? E os filhos? E as outras pessoas que moram na casa?". As falas das trabalhadoras nos debates mostraram, com clareza, a existência de uma divisão sexual e etária das atividades domésticas. As trabalhadoras referem-se à pequena participação dos cônjuges e ex-cônjuges nesses afazeres, o que confirma os dados quantitativos: $90 \%$ das mulheres, mas só $45 \%$ dos homens afirmam realizar afazeres domésticos (Tab. I). Revelam também não ser inteiramente desprezível a participação masculina nesta área ${ }^{7}$, como algumas das participantes dos diversos grupos também relataram:

Eu faço uma lista toda a semana [...] você vai lavar o banheiro, você passa o pano, eu fico com a roupa porque eu sei que ele não lava direito [...]. Eu chego e faço janta, a louça é dele. [...] Porque eu comecei a assumir sozinha, e ele começou a reclamar que eu estava muito cansada, não tinha tempo para outras coisas, para o namoro, eu falei, então vamos dividir [...] Ele falou 'está bom'. Ele ajuda. Só que às vezes, ele esquece e eu tenho que ficar no pé. (28 anos, casada, auxiliar administrativa, I filha)

[...] eu trabalho à noite e o meu esposo trabalha de manhã. Eu cuido do meu filho de manhã e ele cuida à noite. Mas as obrigações que tem de fazer à noite ele faz,

7. Publicação da FIBGE (2002), baseada em dados das PNADs de 1992 e 1999 , apontou significativo incremento da participação dos trabalhadores na realização de afazeres domésticos, passando de 35,8\% em 1992 para 51,2\% em 1999, embora a parcela de mulheres que trabalha e realiza afazeres domésticos concomitantemente mantenha-se na casa dos $90 \%$ (90\% em 1992 e $93,6 \%$ em 1999). 
esquentar comida, se tiver que fazer ele faz, se tiver que dar banho em um [filho] ele dá, faz mamadeira faz tudo. (33 anos, casada, ajudante de cozinha, 2 filhos).

TABELA I

TEMPO DE DEDICAÇÃO AOS AFAZERES DOMÉSTICOS POR PESSOAS DE IO ANOS OU MAIS, SEGUNDO O SEXO ( BRASIL, 2002)

\begin{tabular}{l|c|c|c|c}
\hline Sexo & $\begin{array}{c}\text { Número absoluto } \\
\text { dos que cuidavam } \\
\text { de afazeres } \\
\text { domésticos }\end{array}$ & $\begin{array}{c}\text { Porcentagem dos } \\
\text { que cuidavam } \\
\text { de afazeres } \\
\text { domésticos }\end{array}$ & $\begin{array}{c}\text { Média de horas } \\
\text { semanais dedicadas } \\
\text { aos afazeres } \\
\text { domésticos }\end{array}$ & $\begin{array}{c}\text { Total das pessoas que } \\
\text { responderam à questão } \\
\text { "cuidava de afazeres } \\
\text { domésticos?" }\end{array}$ \\
\hline Feminino & 65.304 .832 & 89,9 & 27,2 & 72.655 .548 \\
Masculino & 30.246 .775 & 44,7 & 10,6 & 67.667 .280 \\
Total & 95.551 .607 & 68,1 & 21,9 & 140.322 .828 \\
\hline
\end{tabular}

Fonte: PNAD microdados (FIBGE,2002).

A divisão sexual se torna mais complexa conforme o tipo de família e a posição no grupo familiar. Constatamos que as cônjuges são as que mais se dedicam às tarefas domésticas: 97\% delas responderam afirmativamente à pergunta sobre sua execução, seguidas pelas chefes e pelas filhas (Tab. 2).

Considerando-se a classificação proposta pelas participantes dos grupos em relação aos afazeres domésticos, fica claro que as crianças significam um importante acréscimo de trabalho em relação à rotina diária, em especial quando pequenas. A dedicação das mães às atividades domésticas declina com o aumento da idade dos filhos: 97\% das mães de filhos de até 2 anos, mas 93\% das mães de filhos de mais de 14 anos cuidavam de tais afazeres por ocasião da pesquisa (Tab.3).

Nos grupos focais, as Chefes mais jovens, com filhos menores e que não contam com o cônjuge para dividir as tarefas, são as mais sobrecarregadas. Algumas, que haviam sido casadas, relataram a participação dos ex-maridos nas tarefas domésticas como "ótimos pais, péssimos maridos". Outras, no entanto, relataram a ausência paterna após a separação: a participação na vida dos filhos passou a se resumir a encontros quinzenais e à pensão alimentícia. $\bigcirc$ dado comum é que a maioria das mulheres deste grupo precisa contar mais com a ajuda de outras mulheres da família: a mãe, às vezes sogras ou tias. 
Família e trabalho...

\begin{tabular}{|c|c|c|c|}
\hline \multicolumn{4}{|c|}{$\begin{array}{c}\text { TABELA } 2 \\
\text { TEMPO DE DEDICAÇÃO AOS AFAZERES DOMÉSTICOS, } \\
\text { SEGUNDO O SEXO E A CONDIÇÃO NA FAMÍLIA (BRASIL, 2002) }\end{array}$} \\
\hline $\begin{array}{c}\text { Sexo e } \\
\text { Condição na família }\end{array}$ & $\begin{array}{l}\text { Número absoluto } \\
\text { dos que cuidavam de } \\
\text { afazeres domésticos }\end{array}$ & \begin{tabular}{|c|} 
Porcentagem dos \\
que cuidavam de \\
afazeres domésticos \\
\end{tabular} & $\begin{array}{c}\text { Média de horas } \\
\text { semanais dedicadas aos } \\
\text { afazeres domésticos }\end{array}$ \\
\hline \multicolumn{4}{|c|}{ - } \\
\hline Pessoa de referência & | 8.458 .779 & 50,0 & 11,2 \\
\hline Cônjuge & 746.276 & 44,2 & $\mid 1,7$ \\
\hline Filho & 9.495 .486 & 37,6 & 9,4 \\
\hline Outro parente & 1.349.405 & 39,4 & 10,6 \\
\hline Agregado & 119.745 & 51,8 & 12,1 \\
\hline Pensionista & 66.987 & 63,8 & 10,1 \\
\hline Empregado doméstico & 9.388 & 54,2 & 20,3 \\
\hline Parente do empr. doméstico & 709 & 42,7 & 10,9 \\
\hline Total masculino & 30.246 .775 & 44,7 & 10,6 \\
\hline \multicolumn{4}{|l|}{ Feminino } \\
\hline Pessoa de referência & 13.517 .259 & 92,2 & 26,7 \\
\hline Cônjuge & 31.890 .064 & 97,3 & 33,4 \\
\hline Filho & 16.192.027 & 79,4 & 16,6 \\
\hline Outro parente & 3.157 .993 & 76,5 & 21,3 \\
\hline Agregado & 253.092 & 87,2 & 20,0 \\
\hline Pensionista & 70.873 & 84,7 & 13,8 \\
\hline Empregado doméstico & 221.869 & 69,0 & 25,2 \\
\hline Parente do empr. doméstico & 1.655 & 58,0 & 19,3 \\
\hline Total feminino & 65.304 .832 & 89,9 & 27,2 \\
\hline Total & 95.551 .607 & 68,1 & 21,9 \\
\hline
\end{tabular}

Fonte: PNAD microdados (FIBGE, 2002).

Obs.: Dentro de cada família as pessoas foram classificadas, na PNAD, em função da relação com a pessoa de referência ou com o seu cônjuge, de acordo com as seguintes definições: Pessoa de referência: responsável pela família ou que assim fosse considerado pelos demais membros; Cônjuge: vivia conjugalmente com a pessoa de referência da família, existindo ou não o vínculo matrimonial; Filho: enteado, filho adotivo ou de criação da pessoa de referência da família ou do seu cônjuge; Outro parente: outro grau de parentesco com a pessoa de referência da família ou com o seu cônjuge; Agregado: era parente da pessoa de referência da família nem do seu cônjuge e não pagava hospedagem nem alimentação; Pensionista: não era parente da pessoa de referência da família nem do seu cônjuge e pagava hospedagem ou alimentação; Empregado doméstico: prestava serviço doméstico remunerado em dinheiro ou somente em benefícios a membro(s) da família; Parente do empregado doméstico: parente do empregado doméstico e não prestava serviço doméstico remunerado a membro(s) da família 
TABELA 3

TEMPO DE DEDICAÇÃO AOS AFAZERES DOMÉSTICOS POR MULHERES QUE TIVERAM FILHOS, SEGUNDO A FAIXA ETÁRIA DO ÚLTIMO FILHO VIVO (BRASIL, 2002)

\begin{tabular}{l|c|c|c}
$\begin{array}{c}\text { Faixa etária do último } \\
\text { filho vivo }\end{array}$ & $\begin{array}{c}\text { Número absoluto } \\
\text { dos que cuidavam de } \\
\text { afazeres domésticos }\end{array}$ & $\begin{array}{c}\text { Porcentagem dos que } \\
\text { cuidavam de afazeres } \\
\text { domésticos }\end{array}$ & $\begin{array}{c}\text { Média de horas } \\
\text { semanais dedicadas aos } \\
\text { afazeres domésticos }\end{array}$ \\
\hline até 2 anos & 6.977 .159 & 97,0 & 34,7 \\
mais de 2 a 4 anos & 4.051 .292 & 96,3 & 32,1 \\
mais de 4 a 5 anos & 1.713 .775 & 96,6 & 31,4 \\
mais de 5 a 6 anos & 1.584 .345 & 95,8 & 30,9 \\
mais de 6 a 7 anos & 1.465 .678 & 96,3 & 31,9 \\
mais de 7 a I4 anos & 8.650 .685 & 96,2 & 30,9 \\
mais de I4 anos & 17.644 .232 & 92,8 & 31,7 \\
ignorado & 780.823 & 83,8 & 27,6 \\
Total feminino & 65.304 .832 & 89,9 & 27,2 \\
Total & 95.551 .607 & 68,1 & 21,9 \\
\hline
\end{tabular}

Fonte: PNAD microdados (FIBGE, 2002).

As Cônjuges em geral, sejam mais velhas ou mais jovens, contam com a ajuda do marido e dos filhos, embora a divisão seja, na maioria das vezes, desigual. Em geral os maridos entram menos nas tarefas de limpeza e arrumação, e mais naquelas relacionadas aos filhos/as. Acompanham o dever de casa, levam e/ou buscam na escola, alimentam, dão banho e trocam roupas e fraldas. Outra tarefa frequente que os homens (tanto marido como filhos) costumam assumir é lavar/secar louça, além do preparo de refeições.

As participantes, porém, nem sempre veem uma distinção sexual na distribuição de tarefas aos filhos/as. Os filhos, assim como as filhas, seriam incentivados à participação, principalmente no que tange à organização e arrumação de suas próprias coisas. Porém, os depoimentos em relação à distribuição sexual das tarefas domésticas são contraditórios. Enquanto "culpam" as mães dos maridos por uma educação pouco igualitária com as tarefas domésticas, reproduzem o mesmo comportamento com seus maridos e filhos: no entanto, como a educação dos filhos é vista como uma atribuição feminina, elas ficam na defensiva em relação à sua própria "culpabilidade" 8 nesta divisão desigual.

Os dados da PNAD 2002 revelam que quase 80\% das meninas de 10 a 14 anos e mais de $86 \%$ das adolescentes de 15 a 19 anos responderam "sim"

8. O termo "culpa" é utilizado frequentemente pelas participantes na discussão da divisão de tarefas. 
Família e trabalho...

à pergunta "cuidava de afazeres doméstico", mas isso foi verdade somente para $41 \%$ dos meninos e $42 \%$ dos adolescentes (Tab. 4). No relato das participantes, pode-se observar a pouca cobrança em relação ao papel dos filhos, assim como é superdimensionada a não-participação das filhas:

Eu tenho um [filho] de 19 que trabalha fora, que já tem a vidinha dele de solteiro, e tenho a de 14 e o de 4 . Eu acho que vai da personalidade porque o meu filho de 4 pega a vassoura, quer passar o pano, quer tirar o pó, quer fazer, quer ajudar a lavar uma louça e a B. (filha) não suporta ! Ela não ajuda em nada!" (38 anos, separada, diagramadora, 3 filhos)

meu marido ajuda, geralmente não sobra muita coisa pra ele, porque eu divido. Eu tenho uma menina de 13 anos, uma menina de 8 e o menino de 16. [...] quando ele chega [o filho de 16 anos] sobra pra ele cuidar da menina menor, [...] se tiver alguma coisa pra ele fazer, ele vai e faz, mas não é todo dia. [...] arruma o quarto, se precisar comprar alguma coisa é ele que vai, sempre é ele, alguma coisinha que está precisando comprar é ele que vai e tem a menina que trabalha mais. Lava a louça, varre a casa, só não lava a roupa porque eu não gosto. No final de semana, a faxina fica para nós duas, eu libero o menino e fica só nós. (38 anos, casada, agente de apoio escolar, 3 filhos).

Os depoimentos ilustram, com riqueza de detalhes, o que nos mostram os dados da pesquisa quantitativa: enquanto cerca de $80 \%$ das filhas cuidam das tarefas domésticas da casa, pouco menos de 38\% dos filhos o fazem (Tab. 2). Muitas meninas são logo "emancipadas" para cuidar do trabalho doméstico em tenra idade, 9 ou 10 anos. Esses depoimentos, assim como os dados da PNAD/2002 evidenciam a contínua reprodução de valores assimétricos de gênero no interior das famílias.

O que observamos neste tópico é que, na maioria dos domicílios das participantes, a segregação de papéis masculinos e femininos a espaços públicos e privados segue como uma divisão fundamental. No entanto, a participação masculina está presente. Aparentemente, as mudanças demográficas e sociais (famílias menores, aumento das famílias chefiadas por mulheres, ingresso das mulheres no mercado de trabalho etc.) acabam por impulsionar alguma mudança em direção a uma distribuição mais simétrica da divisão sexual do trabalho doméstico, mais acentuada em relação aos companheiros, do que aos filhos/as. 
TABELA 4

TEMPO DE DEDICAÇÃO AOS AFAZERES DOMÉSTICOS, SEGUNDO O SEXO E A FAIXA ETÁRIA (BRASIL, 2002)

\begin{tabular}{l|c|c|c}
\multicolumn{1}{|c|}{ Sexo e Faixa etária } & $\begin{array}{c}\text { Número absoluto } \\
\text { dos que cuidavam de } \\
\text { afazeres domésticos }\end{array}$ & $\begin{array}{c}\text { Porcentagem dos que } \\
\text { cuidavam de afazeres } \\
\text { domésticos }\end{array}$ & $\begin{array}{c}\text { Média de horas } \\
\text { semanais dedicadas aos } \\
\text { afazeres domésticos }\end{array}$ \\
\hline Masculino & 3.392 .497 & 40,7 & 8,9 \\
I0 a I4 anos & 3.590 .003 & 41,5 & 9,8 \\
I5 a I9 anos & 3.235 .426 & 40,0 & 9,8 \\
20 a 24 anos & 3.039 .942 & 45,7 & 10,1 \\
25 a 29 anos & 5.988 .413 & 48,8 & 10,5 \\
30 a 39 anos & 4.702 .981 & 47,3 & 10,4 \\
40 a 49 anos & 3.117 .757 & 46,8 & 11,8 \\
50 a 59 anos & 3.179 .756 & 45,1 & 14,0 \\
60 anos ou mais & 30.246 .775 & 44,7 & 10,6 \\
Total masculino & & & 14,2 \\
Feminino & 6.351 .099 & 77,2 & 20,1 \\
I0 a I4 anos & 7.356 .748 & 86,4 & 25,0 \\
I5 a I9 anos & 7.170 .635 & 87,4 & 28,7 \\
20 a 24 anos & 6.571 .568 & 91,9 & 29,9 \\
25 a 29 anos & 12.547 .427 & 94,8 & 30,8 \\
30 a 39 anos & 10.495 .206 & 95,3 & 32,9 \\
40 a 49 anos & 7.004 .206 & 95,5 & 30,6 \\
50 a 59 anos & 7.807 .943 & 87,0 & 27,2 \\
60 anos ou mais & 65.304 .832 & 89,9 & 2,9 \\
\hline Total feminino & 95.551 .607 & & \\
\hline Total & & & \\
\hline
\end{tabular}

Fonte: PNAD microdados (FIBGE, 2002).

\section{O USO DO TEMPO NA REALIZAÇÃO DOS AFAZERES DOMÉSTICOS}

As investigações sobre o tempo têm tido papel importante no sentido de desvendar pequenas e fragmentadas atividades que, de outra forma, teriam permanecido invisíveis. Ainda que os estudos de orçamento-tempo sejam limitados em certos aspectos e de metodologia complexa, em determinado momento eles serviram para completar informações e verificar discursos, além de contribuir para a visibilização do trabalho doméstico (Bruschini, 2006).

Considerando o uso do tempo pelas participantes dos grupos focais, encontramos um cotidiano exaustivo, com pouco ou nenhum tempo para descanso, lazer e/ou aperfeiçoamento profissional, confirmada pela análise dos dados da PNAD 2002. 
Família e trabalho..

Conforme dados mais gerais a respeito do tempo de dedicação aos afazeres domésticos, o diferencial de gênero se apresenta com clareza. Enquanto na população total este número foi de 21,9 horas semanais, o das mulheres foi cerca de 27 horas e o dos homens pouco menos de II horas (Tab. I). As mulheres costumam ter jornadas mais curtas na atividade produtiva e arranjos de trabalho mais precários que os dos homens, fato já confirmado na literatura sobre gênero. $O$ tempo global gasto, ao somar atividades produtivas ou remuneradas com as reprodutivas, revela que, enquanto os homens gastam um número maior de horas por semana do que as mulheres nas atividades consideradas produtivas ( 49 horas eles e 43 horas elas), a contrapartida das mulheres é que o tempo delas em atividades domésticas, na esfera da reprodução, é bem maior do que o deles ( 21 horas elas, 10 horas eles). Ou seja, o tempo total gasto é muito mais elevado entre elas (63,6 horas) do que entre eles (58,6 horas). Note-se que estão inclusas neste tempo total as horas gastas com o percurso de ida e volta da residência para o local de trabalho, que é igual para ambos os sexos (4,7 horas por semana, Tab. 5).

TABELA 5

TEMPO DEDICADO À PRODUÇÃO E À REPRODUÇÃO POR SEXO (BRASIL, 2002)

\begin{tabular}{c|c|c|c|c|c}
\hline & \multicolumn{3}{|c|}{ Produção } & Reprodução & Total \\
\hline Sexo & $\begin{array}{c}\text { N. médio } \\
\text { de horas } \\
\text { trabalhadas } \\
\text { percurso } \\
\text { médio de ida } \\
\text { da residência } \\
\text { para o local de } \\
\text { trabalho }\end{array}$ & Total & $\begin{array}{c}\text { N. médio de } \\
\text { horas dedicadas } \\
\text { aos afazeres } \\
\text { domésticos }\end{array}$ & $\begin{array}{c}\text { Tempo total } \\
\text { gasto em } \\
\text { atividades de } \\
\text { produção e } \\
\text { reprodução }\end{array}$ \\
\hline Mulheres & 38,3 & (B) & (A+B) & (C) & $(\mathrm{A}+\mathrm{B}+\mathrm{C})$ \\
\hline Homens & 44,3 & 4,7 & 43,0 & 20,6 & 63,6 \\
\hline
\end{tabular}

Fonte: PNAD microdados (FIBGE, 2002).

O número médio de horas de trabalho doméstico, para homens e mulheres, costuma elevar-se com a idade. Entre as mulheres, esse aumento é significativo a partir dos 25 anos (28,7 horas semanais) e atinge seu pico (32,9 horas) na faixa de 50 a 59 anos. A partir dos 60 anos, esse tempo tem um pequeno decréscimo. A relação é mais linear entre os homens, elevando-se progressivamente de 8,9 horas (de 10 a 14 anos) até 14 horas, quando atinge o seu pico na última faixa 
etária considerada (60 anos ou mais). Vale ressaltar a acentuada diferença do número de horas dedicadas aos afazeres domésticos entre meninos e meninas (faixa etária de 10 a 14 anos): enquanto elas trabalham mais de 14 horas por semana em afazeres domésticos, eles dedicam a essas tarefas menos de 9 horas. Quando ficam mais velhos, a partir dos 60 anos, os homens aumentam sua dedicação ao trabalho doméstico, mas não atingem sequer a metade do tempo gasto pelas mulheres da mesma faixa etária: 14 horas eles, 30,6 elas (Tab. 4).

Na presença de filhos, o ritmo de atividade é mais intenso, principalmente entre as mulheres mais jovens, que usualmente têm filhos menores, como acontece no grupo de Chefes mais jovens. Como revelam os dados da tabela 3 , cerca de 35 horas semanais são dedicadas aos afazeres domésticos por mulheres que têm filhos menores de 2 anos, mas esse número declina com o aumento da idade deles. A rotina das trabalhadoras mães de filhos pequenos poderia ser assim resumida, como nos informam seus relatos: a jornada na atividade produtiva é de 8 horas por dia, porém, antes de sair para o trabalho, elas deixam o(s) filho(s) na creche, escolinha ou outro lugar para serem cuidados, como a casa da mãe/sogra/vizinha etc. Demoram de I h30 a 2 horas na ida e o mesmo tempo para a volta do trabalho. Buscam os filhos, chegam em casa e dão conta das tarefas domésticas que não podem adiar para o fim de semana, como alimentação, arrumação de material escolar e até arrumação, limpeza e cuidado com roupas, no que gastam cerca de 3 horas diárias:

...eu chego da faculdade I I h30, ainda vou arrumar mochila do filho, vou lavar roupa dele, quando eu vejo já são 3 da manhã, no outro dia 6 da manhã estou de pé $[. .$.$] Tem os trabalhos da faculdade para fazer no final de semana, então$ além de passar o dia inteiro esquenta no fogão e esfria no tanque, tem que sentar no computador tendo ideias. (25 anos, solteira, inspetora de alunos, I filho)

As horas de afazeres domésticos avançam no período que deveria ser de descanso, porém muitas tarefas são inadiáveis. A possibilidade de estas jovens mães de baixa renda continuarem os estudos é bastante pequena, representando enormes sacrifícios a quem se submete a esta rotina tripla (família/ trabalho/estudo). A escolaridade é a variável que tem mais influência sobre o tempo gasto na atividade doméstica, para homens e mulheres, pois quanto mais elevada, menor o número de horas gastas nos afazeres domésticos. Enquanto os homens sem instrução dedicam 12 horas semanais aos afazeres 
Família e trabalho..

domésticos, as mulheres na mesma condição consomem nessas atividades mais de 31 horas. Entre aqueles/as com mais de 12 anos de instrução eles dedicam 9 horas e elas, 20 horas, pouco mais do que o dobro (Tab. 6). O número de horas também diminui, para homens e mulheres, à medida que o rendimento aumenta (Tab. 7), o que é compreensível, já que o aumento do rendimento da família possibilita a aquisição de equipamentos que poupam o tempo consumido nas atividades domésticas ${ }^{9}$ e a contratação de auxílio remunerado externo, deixando a relação um pouco menos desigual.

TABELA 6

TEMPO DE DEDICAÇÃO AOS AFAZERES DOMÉSTICOS, SEGUNDO O SEXO E A FAIXA DE ANOS DE ESTUDO (BRASIL, 2002)

\begin{tabular}{|c|c|c|c|}
\hline Sexo e Faixa de anos de estudo & $\begin{array}{l}\text { Número absoluto } \\
\text { dos que cuidavam de } \\
\text { afazeres domésticos }\end{array}$ & $\begin{array}{c}\text { Porcentagem } \\
\text { dos que } \\
\text { cuidavam } \\
\text { de afazeres } \\
\text { domésticos } \\
\end{array}$ & $\begin{array}{c}\text { Média de } \\
\text { horas semanais } \\
\text { dedicadas } \\
\text { aos afazeres } \\
\text { domésticos }\end{array}$ \\
\hline \multicolumn{4}{|l|}{ Masculino } \\
\hline Sem instrução e menos de I ano & 3.147 .143 & 38,8 & 12,2 \\
\hline de I a 4 anos & 8.734 .723 & 42,2 & 10,7 \\
\hline de 5 a 8 anos & 9.011 .719 & 46,4 & 10,6 \\
\hline de 9 a II anos & 6.617 .623 & 47,9 & 10,4 \\
\hline 12 anos e mais & 2.515 .970 & 48,5 & 9,1 \\
\hline Não determinado e sem declaração & 219.597 & 53,0 & 10,6 \\
\hline Total masculino & 30.246 .775 & 44,7 & 10,6 \\
\hline \multicolumn{4}{|l|}{ Feminino } \\
\hline Sem instrução e menos de I ano & 7.502 .383 & 88,2 & 31,1 \\
\hline de I a 4 anos & | 8.766 .488 & 90,7 & 28,9 \\
\hline de 5 a 8 anos & | 8.566 .185 & 92,0 & 27,2 \\
\hline de 9 a II anos & | 4.797.835 & 90,4 & 25,4 \\
\hline 12 anos e mais & 5.250 .893 & 81,3 & 20,0 \\
\hline Não determinado e sem declaração & 421.048 & 93,9 & 27,0 \\
\hline Total feminino & 65.304 .832 & 89,9 & 27,2 \\
\hline Total & 95.551 .607 & 68,1 & 21,9 \\
\hline
\end{tabular}

Fonte: PNAD microdados (FIBGE, 2002).

9. Entretanto, alguns estudos (Dedecca, 2004) comentam que a presença de equipamentos domésticos mais sofisticados não reduz a carga horária doméstica das famílias em inúmeros países europeus por ele estudados. 
TABELA 7

TEMPO DE DEDICAÇÃO AOS AFAZERES DOMÉSTICOS, SEGUNDO O SEXO E A FAIXA DE RENDIMENTO DO TRABALHO PRINCIPAL (BRASIL, 2002)

\begin{tabular}{|c|c|c|c|}
\hline $\begin{array}{l}\text { Sexo e Faixa de rendimento } \\
\text { do trabalho principal }\end{array}$ & $\begin{array}{l}\text { Número absoluto } \\
\text { dos que cuidavam de } \\
\text { afazeres domésticos }\end{array}$ & $\begin{array}{l}\text { Porcentagem dos } \\
\text { que cuidavam de } \\
\text { afazeres domésticos }\end{array}$ & $\begin{array}{c}\text { Média de horas } \\
\text { semanais dedicadas } \\
\text { aos afazeres } \\
\text { domésticos }\end{array}$ \\
\hline \multicolumn{4}{|l|}{ Masculino } \\
\hline sem rendimento até I SM & 6.486 .073 & 43,4 & 10,3 \\
\hline mais de I a 3 SM & 8.480 .075 & 44,8 & 9,9 \\
\hline mais de 3 a 5 SM & 2.582 .122 & 47,7 & 9,4 \\
\hline mais de 5 a 10 SM & ।.77।.348 & 47,2 & 8,6 \\
\hline mais de 10 e rend. ignorado & 1.215 .235 & 42,8 & 7,8 \\
\hline Total masculino & 30.246 .775 & 44,7 & 10,6 \\
\hline \multicolumn{4}{|l|}{ Feminino } \\
\hline sem rendimento até I SM & 14.933 .925 & 93,8 & 26,1 \\
\hline mais de I a 3 SM & $|0.203 .03|$ & 90,1 & 20,5 \\
\hline mais de 3 a 5 SM & 2.010 .538 & 86,6 & 18,8 \\
\hline mais de 5 a 10 SM & 1.419 .606 & 83,8 & 17,5 \\
\hline mais de 10 e rend. ignorado & 800.346 & 76,9 & 16,7 \\
\hline Total feminino & 65.304 .832 & 89,9 & 27,2 \\
\hline Total & 95.551 .607 & 68,1 & 21,9 \\
\hline
\end{tabular}

Fonte: PNAD microdados (FIBGE, 2002).

Pode-se constatar como as trajetórias profissionais femininas são permeáveis às necessidades familiares, em particular ao cuidado infantil. Os depoimentos a seguir ilustram trajetórias que oscilam entre empregos formais, com jornadas fixas e mais extensas, e outros informais, com jornadas flexíveis. Esses depoimentos são confirmados pelos dados da tabela 8, segundo os quais, enquanto as trabalhadoras com carteira dedicam aos afazeres domésticos 18 horas semanais, as que trabalham por conta própria gastam 27 horas com tais tarefas $^{10}$ :

10. Nem sempre a categoria "autônoma" significa um horário de trabalho mais flexível. Algumas participantes se denominavam autônomas por prestar serviços por meio de cooperativas, todavia possuíam rígida jornada de trabalho a cumprir. Ao que parece, em muitos casos o cooperativismo tem servido para burlar as leis trabalhistas vigentes. 
Família e trabalho...

Eu trabalhei numa gráfica e ganhava bem, só que eu saia 4h30 da manhã e voltava 9 h30 da noite, os meus filhos ficavam esse espaço inteiro [sozinhos]. Daí eu preferi ganhar menos, mas ficar mais tempo com os meus filhos. [...] (38 anos, casada, agente de apoio escolar, 3 filhos)

Eu abri mão também, eu era operadora de caixa no [supermercado], eu abri mão desse emprego por causa dos meus filhos, praticamente eu trabalhava direto. $\bigcirc$ gerente sempre pedia para eu cobrir horário de janta e os meus filhos ficavam praticamente sozinhos. [...] era um bom emprego [...] [Hoje eu trabalho] Em casa de família, isso me ajudou muito, porque eu fico mais tempo com os meus filhos. (36 anos, casada, doméstica, 2 filhos)

Eu trabalhava numa metalúrgica e na época que eu tive o M., ele é prematuro de 6 meses e meio, então ou eu confiava em alguém para cuidar dele ou eu... Eu tinha oportunidade de crescer profissionalmente, mas eu corria o risco do M. não ter os devidos cuidados, daí eu falei "deixa o trabalho para lá e vamos cuidar do filho". Mas eu não me arrependo não, eu acho que vale a pena. (36 anos, casada, copeira de buffet, 2 filhos)

TABELA 8

TEMPO DEDICADO AOS AFAZERES DOMÉSTICOS POR MULHERES, SEGUNDO A POSIÇÃO EM OCUPAÇÕES SELECIONADAS (BRASIL, 2002)

\begin{tabular}{l|c}
\hline \multicolumn{1}{c|}{ Posição na ocupação } & $\begin{array}{c}\text { Média de horas semanais dedicadas aos } \\
\text { afazeres domésticos }\end{array}$ \\
\hline empregada com carteira & 18,2 \\
\hline empregada sem carteira & 20,7 \\
\hline trabalhadora doméstica com carteira & 20,5 \\
\hline trabalhadora doméstica sem carteira & 23,4 \\
\hline funcionária pública estatutária & 21,8 \\
\hline conta própria & 27 \\
\hline empregadora & 18,2 \\
\hline População brasileira feminina ocupada & 23
\end{tabular}

Fonte: PNAD microdados (FIBGE, 2002).

Normalmente, devido à jornada diária de 8 horas, pelo menos 10 horas do dia estão ocupadas com o emprego. Todas recorrem a alguma ajuda, remunerada ou não (mas em geral de alguém do sexo feminino, como os dados da tabela 2 revelam). 
Foi no grupo de Cônjuges mais novas que encontramos alguns dos arranjos mais igualitários de divisão de tarefas. Conforme a negociação e o acordo estabelecido pelo casal, a presença do cônjuge pode-se traduzir em uma melhor divisão das tarefas, assim como na produção de mais trabalho. De todas as mulheres, as cônjuges são as que trabalham o número mais elevado de horas - 33,4- em afazeres domésticos, seguidas das chefes de família, das filhas, parentes do sexo feminino e empregadas domésticas (Tab. 2).

No grupo das Chefes mais velhas, a rotina é um pouco menos apertada. Com filhos mais velhos, as mães ficam livres de algumas tarefas centradas nos filhos pequenos. Ainda que discreta, parece haver redução no número de horas em afazeres domésticos neste grupo em relação ao de Chefes mais jovens. Há uma rotina diária menos exaustiva, e a possibilidade de escolher entre fazer as tarefas de maneira fragmentada durante a semana ou concentrar em seu final, diferentemente dos relatos do grupo anterior, em que transparece a necessidade das mães utilizarem todo o seu tempo disponível. Todavia, algumas participantes do grupo de Chefes mais velhas afirmam que a realização de afazeres domésticos no fim de semana ocupa "o tempo todo": "Final de semana ou você está na feira, ou você está no mercado, ou você está no açougue" (44 anos, separada, vendedora autônoma, 3 filhos).

O tempo gasto com afazeres domésticos entre Chefes e Cônjuges mais novas é semelhante, com a diferença de que o uso do tempo diário para as segundas parece ser menos exaustivo, pois, ainda que a divisão do trabalho não seja simétrica entre casais, há uma distribuição maior de tarefas, principalmente no que tange aos filhos pequenos, que são os que mais consomem tempo de cuidado. Todavia, pode-se observar, como uma constante no discurso das participantes, a rotina diária e até a vida profissional intensamente condicionada aos filhos, arranjada de maneira a propiciar um acompanhamento da educação, atividades e problemas relacionados a esses, seja entre as casadas ou entre as chefes de família.

\section{ESTRATÉGIAS DE CONCILIAÇÃO ENTRE TRABALHO E FAMÍLIA: CRECHES E ARRANJOS PRECÁRIOS}

As creches e as escolas de educação infantil" têm sido vistas, desde meados da década de 1980, como um direito da criança, e não só das mães

I I. Embora, como afirmam Kappel, Kramer, Carvalho (200I, p.35-36), existam vários critérios para definir as modalidades de educação infantil, as definições contidas no artigo 30, da Lei de 
Família e trabalho...

trabalhadoras. Foi a partir da década de 1980 que o número de creches teve importante crescimento, porém, nunca chegou a um patamar satisfatório em relação à demanda. A política pública de educação infantil, no entanto, ainda é um importante fator para o ingresso das mães no mercado de trabalho, além de contribuir para a elevação da renda familiar e dos salários femininos dos domićlilos com crianças atendidas por creches (Sorj, 2004b).

Os dados da PNAD/FIBGE, 2002 revelam que a rede de creches e préescolas no país está longe de atender à demanda da população em geral e das trabalhadoras em particular. Pouco mais de $36 \%$ das crianças brasileiras de 0 a 6 anos, em 2002, frequentavam creche ou pré-escola, mas apenas $11,7 \%$ daquelas de 0 a 3 anos frequentavam uma creche na mesma data (Tab. 9). Se essa constatação é grave da perspectiva dos direitos das crianças, assegurados pela legislação brasileira, também é extremamente relevante do ponto de vista das necessidades das trabalhadoras. Elas atribuem precisamente às creches a estratégia mais importante para auxiliá-las nessa conciliação.

TABELA 9

FREQUÊNCIA A CRECHE OU PRÉ-ESCOLA, SEGUNDO A IDADE DAS CRIANÇAS E REDE DE ENSINO (BRASIL, 2002)

\begin{tabular}{|c|c|c|c|c|c|c|c|c|c|}
\hline \multirow{3}{*}{$\begin{array}{l}\text { Faixa } \\
\text { etária } \\
\text { infantil }\end{array}$} & \multirow{3}{*}{$\begin{array}{c}\text { Total de } \\
\text { crianças de } \\
\text { até } 6 \text { anos }\end{array}$} & \multirow{2}{*}{\multicolumn{2}{|c|}{$\begin{array}{c}\text { Frequentam creche } \\
\text { ou pré-escola }\end{array}$}} & \multicolumn{6}{|c|}{ Rede de ensino } \\
\hline & & & & \multicolumn{2}{|c|}{ Pública } & \multicolumn{2}{|c|}{ Particular } & \multicolumn{2}{|c|}{ Outra } \\
\hline & & NA & $\%$ & NA & L \% & NA & L \% & NA & L \% \\
\hline 0 a 3 anos & || $.8 \mid 1.025$ & |.377.683 & 11,7 & 722.746 & 52,5 & 649.996 & 47,2 & 4.941 & 0,4 \\
\hline 4 anos & 3.159 .578 & 1.452 .425 & 46,0 & 877.587 & 60,4 & 572.792 & 39,4 & 2.046 & 0,1 \\
\hline 5 anos & 3.189 .488 & 2.147 .872 & 67,3 & 1.536 .185 & $7 \mid, 5$ & 609.058 & 28,4 & 2.629 & 0,1 \\
\hline 6 anos & 3.310 .631 & 2.869 .129 & 86,7 & 2.267 .347 & 79,0 & 599.637 & 20,9 & 2.145 & 0,1 \\
\hline Total & 21.470 .722 & 7.847 .109 & 36,5 & 5.403 .865 & 68,9 & 2.431 .483 & 31,0 & $|1.76|$ & 0,1 \\
\hline
\end{tabular}

Fonte: PNAD microdados (FIBGE, 2002).

Uma das principais queixas das participantes dos grupos focais é justamente a falta de vagas: "Teve uma creche na [Av.] Anhaia Melo que uma vez eu passei lá a noite, as pessoas estavam na fila 3 dias antes, e a creche é enorme [...] Você pode dormir 3 dias e não é garantido conseguir" (26 anos,

Diretrizes e Bases da Educação Nacional - LDB -, são as seguintes: I - creches, ou entidades equivalentes, para crianças de até três anos de idade; II - pré-escolas, para as crianças de quatro a seis anos de idade. 
divorciada, auxiliar administrativa, 2 filhos). A idade da criança influencia suas chances de ingresso:

Eu estou pleiteando uma vaga para a minha filha. A minha irmã colocou os dois filhos dela e conseguiu. Só que a idade que ela [filha] está é meio complicada para entrar agora [...] Porque não tem vaga para um ano e oito meses. É mais fácil conseguir com menos no berçário do que estando nessa idade. (28 anos, casada, auxiliar administrativa, I filho)

Caso a criança não seja inscrita logo aos 4 meses, idade inicial para atendimento nas creches, a sua chance de conseguir vaga diminui consideravelmente, principalmente em regiões com menor número de estabelecimentos. Aquelas mães que, por um motivo ou outro, optam por retornar um pouco mais tarde ao mercado de trabalho podem ter dificuldade em conseguir uma vaga. Porém, quando conseguem matricular suas crianças, o problema a ser enfrentado é o horário, inadequado para quem tem uma jornada de trabalho integral padrão (normalmente das 8 horas às 17 horas ou das 9 horas às 18 horas), tendo em vista que a maioria das creches funciona no horário das 7 horas às 16 horas. Apenas uma das participantes relatou um horário de creche que funcionava 12 horas por dia, das 7 horas às 19 horas. São diversas as estratégias adotadas para adaptar-se aos horários disponíveis. Muitas vezes recorrem a arranjos precários, devido ao horário inadequado das creches:

Eu punha a minha filha embaixo da mesa e falava: "Senta aí, deita". Eu ficava até nove, dez da noite trabalhando. Eu chegava na padaria e comprava um lanche pra ela, punha embaixo da mesa e ela ficava ali comendo. [...] E eu não podia virar as costas para o meu trabalho. E eu não tinha quem ficasse com ela. (40 anos, divorciada, representante de vendas, 2 filhos).

Geralmente não é adequado [o horário das creches] porque entra às sete e sai quatro, quatro e meia [...] E outra, uma vez por mês elas param na sexta-feira para fazer coordenação pedagógica. (28 anos, casada, auxiliar administrativa, I filho).

Não obstante, é interessante verificar que a proporção de utilização da rede pública e privada de educação infantil altera-se significativamente quando 
Família e trabalho...

observada a idade da criança. Na faixa de 0 a 3 anos a proporção é quase equilibrada, isto é, dos 11 ,7\% de crianças matriculadas em creche/pré-escola com esta idade, 52,5\% estão na rede pública e 47,2\% nos estabelecimentos particulares. Essa proporção vai se alterando com a idade da criança: com 6 anos, a proporção de crianças atendidas é de $86,7 \%$, mas, desse contingente, $79 \%$ estão em rede pública e 20,9\% na particular (Tab. 9). Esses dados vão ao encontro da opinião de muitas entrevistadas, que preferem não deixar bebês sob a guarda de estranhos, retardando sua volta ao mercado de trabalho ou mesmo contando com o auxílio de parentes. Quando não têm essas alternativas, algumas optam por apertar o orçamento já pequeno e colocar em "escolinhas" privadas ${ }^{12}$. Às vezes, os motivos são de ordem prática: porque o horário é mais adequado do que o das creches públicas, ou porque sua localização é mais próxima ao trabaIho, o que facilita no momento de buscar a criança. Vale ressaltar que o tempo de transporte na região metropolitana de São Paulo é um fator importante a se considerar para organizar o uso do tempo ${ }^{13}$, daí a importância dos horários e da localização (próxima ao trabalho ou ao domicílio).

No entanto, algumas vezes a razão da preferência pela rede particular é o medo de maus-tratos e a concepção de que, quando o serviço é público (portanto, visto como gratuito, apesar de sustentado com impostos) não se pode "cobrar" um atendimento de qualidade: "Eu optei, porque olhava a pública com medo, na particular eu sei que posso cobrar e é na rua do meu serviço." (26 anos, divorciada, auxiliar administrativa, 2 filhos).

A aprovação majoritária do serviço de creches públicas, da prefeitura ou do governo estadual, não excluiu o relato de alguns problemas nos grupos, envolvendo histórias de conhecidos/familiares que assinalam maus-tratos e certa frieza das profissionais das creches:

Eu nunca gostei de creche. [...] Eu preferia pagar uma vizinha para cuidar dos meus filhos $[\ldots ..] \bigcirc$ meu receio era o bebê. Ninguém vinha pegar no colo e

12. Apesar da definição da LDB sobre a distinção entre creches e pré-escolas, para as entrevistadas o termo "creche" designava os estabelecimentos públicos e "escolinha" como os similares da rede privada.

13. A problemática da combinação dos diversos tempos da cidade como política urbana e sua importância para a equidade de gênero foi abordada no trabalho de Belloni, Boulin, JunterLoiseau (2003). 
depois dar mamadeira, tinha que pôr no bercinho. Eu não aceitei esta ideia. (28 anos, casada, técnica em enfermagem, 2 filhos)

Recentemente eu conheci uma creche, do meu neto de I ano e meio [...] tinha uma criança chorando bastante, bateu a cabeça [...] eu acho que elas judiam um pouquinho, elas deveriam ter um pouco mais de carinho pelas crianças. Eu acho que elas fazem só profissionalmente mesmo. (43 anos, casada, vendedora de seguros, 3 filhos)

Percebe-se, portanto, que ainda há resistência a deixar os filhos, em especial os pequenos, com "estranhos". No entanto, muitas avaliaram positivamente as creches, ressaltando o cumprimento de um papel educacional:

...e a minha se adaptou muito bem à creche. [Aprendeu] Muitas brincadeiras porque ela foi criada praticamente com adultos, eu, meu esposo, minha mãe. Não tinha crianças para ela brincar. $\bigcirc$ desenvolvimento dela foi tão rápido e tão progressivo que eu acabei me adaptando muito bem e sem receio algum. [...] Eles [os filhos] começam a ter horário, eles começam a ser organizados e começam a ter regras [...] Uma rotina, porque em casa, a gente, mãe, estraga o filho. (34 anos, casada, ajudante geral, I filho)

Eu acho que as crianças que vão para creche elas amadurecem mais rápido. (33 anos, casada, ajudante de cozinha, 2 filhos)

A educação infantil, conquistada como um direito da criança, é também um importante instrumento de conciliação de trabalho e família. Algumas participantes criticaram as mães que deixavam os filhos na creche, mas não trabalhavam:

Eu até fiquei brava, porque não é para as mães que trabalham? Você não tem um controle disso. Porque você vê que, às vezes, a mãe vai de chinelo levar e na hora de buscar está do mesmo jeito, então, você percebe que não está trabalhando. A moça até me abriu os olhos, ela falou: mas a creche é para todos. (28 anos, casada, auxiliar administrativa, I filho) 
Família e trabalho...

Ainda que o direito universal das crianças à educação seja indiscutível, a ainda restrita rede de creches e pré-escolas faz com que a maioria das participantes ache justa alguma seleção socioeconômica. Porém, a visão predominante entre as participantes dos grupos foi a de que a creche é um direito das mulheres e uma política para possibilitar seu trabalho. Fica claro, neste tópico, o forte impacto da política de educação infantil sobre o trabalho feminino. $\bigcirc$ auxílio-creche, benefício assegurado em lei, é reduzido aos trabalhadores com vínculo empregatício formal, resultando em uma evidente desigualdade entre aquelas que estão no formal ou informal. No Brasil, de acordo com a legislação trabalhista, a creche é um dos itens que deve ser financiado pelo empregador, diretamente associado ao trabalho feminino ${ }^{14}$, com o pagamento de auxílio nas empresas com mais de 30 empregadas acima de 16 anos.

\section{POLÍTICAS SOCIAIS QUE FAVORECEM A CONCILIAÇÃO ENTRE TRABALHO E FAMÍLIA}

No âmbito das políticas de responsabilidade estatal, as participantes apontaram a ausência de opções de lazer nos bairros como um problema comum. Elas alegaram falta de opções de atividades de esporte/lazer e educação extraescolar, atividades que ajudariam a ocupar o restante do dia em que os filhos não estão mais na escola, período no qual as mães ainda estão trabalhando:

Eu acho assim, que cada bairro deveria ter o seu lugar de lazer para aquelas crianças que não são mais daquelas áreas de creche. Porque saía da escola ia para aí. Tinha uma professora, alguma tia para ajudar a fazer aquela lição de casa, um cuidado ajudaria a gente, quando a gente chegasse em casa já tinha a lição e a gente poderia dar uma olhada. (33 anos, casada, ajudante de cozinha, 2 filhos)

A questão do lazer também está associada ao cuidado dos filhos. A creche é uma política que costuma ter horário integral - mesmo quando inapropriado,

14. Apesar de ser um custo diretamente associado ao trabalho das mulheres, alguns estudos, como o de Abramo, (2005, p.32-36) contestam a ideia de que o custo do trabalho feminino é muito maior que o masculino, em especial no que diz respeito às creches, pois o custo desse serviço resulta em um acréscimo de apenas $0,3 \%$ da remuneração mensal bruta das mulheres. 
como se viu -, mas que finda com a idade de 7 anos, quando as crianças ainda não podem ser deixadas sozinhas. $\bigcirc$ problema é mais grave nas cidades com a alta incidência de violência urbana. A preocupação manifestada pelas participantes é originada pelo longo lapso de tempo entre o fim do horário escolar e o retorno de pais e mães do trabalho, em que as crianças e adolescentes poderiam ser cuidados e/ou supervisionados, além da frequente ausência de professores na rede pública.

Outra política citada, mas que se restringe aos alunos de escolas da rede municipal, é o transporte escolar: essa política aparentemente simples foi elogiada pelas participantes, que tem direito ao transporte caso morem a, pelo menos, I km da escola, ou haja travessia de avenida. Porém, segundo os depoimentos, o transporte escolar não cobre os horários de educação física, muitas vezes fora do horário regular de aulas, o que causa transtornos e uma tarefa a mais para as famílias.

Em relação às políticas que poderiam ser proporcionadas pelas empresas, as sugestões não apresentaram novidade em relação ao que já se conhece e ao que a lei trabalhista exige. $\bigcirc$ problema maior é justamente o não-cumprimento dessas normas, seja porque as mães têm vínculo informais de emprego (muitas vezes, como se viu, irregulares, como no caso de certas cooperativas), seja porque as empresas não as cumprem apesar de "assinarem a carteira".

Além de citarem os benefícios de creche, licença-maternidade e amamentação, as mães que têm uma jornada mais rígida reclamaram da pouca flexibilidade dos empregadores:

Se você não vai numa reunião do seu filho, a professora fala: passa e leva uma declaração, você entrega aquilo, simplesmente você está falando para o seu chefe, eu não estou mentindo, mas aquilo não tem significado nenhum. Você não vai receber. Então, às vezes, você pensando em não perder aquele dinheiro que vai te fazer falta você manda a avó, manda uma prima. (35 anos, casada, recepcionista, 2 filhos)

Ainda que o auxílio-creche seja uma obrigação legal, o compromisso com a educação dos filhos não finda aí. Participantes da pesquisa apontaram como desejáveis auxílios para pagamento de escolas/colégios: 
Família e trabalho...

Devia dar [auxílio-creche] para eles [filhos/as] no caso de criança até seis anos, e depois até os 15 [anos] receber auxílio também. (34 anos, casada, auxiliar de enfermagem, 3 filhos).

Um convênio em alguma escola, facilidade em creche. Vamos supor que você trabalhasse num supermercado, então esse supermercado teria acesso à creche, o supermercado já te daria um papel de encaminhamento para você deixar seu filho na creche. (26 anos, divorciada, auxiliar administrativa, 2 filhos)

Essas sugestões são ilustrativas para avaliar o papel das empresas como vetores de políticas sociais no setor privado, que usualmente é pequeno e restrito a poucos estabelecimentos e de grande porte. Pesquisas anteriores constataram que, mesmo em empresas de ponta, os benefícios vão pouco além do que exige a legislação (Bruschini, Ridenti, 1995). Pesquisa mais recente realizada pelo Instituto de Pesquisa Econômica Aplicada - IPEA (2006) sobre a ação social das empresas mostra que, apesar de ser de considerável monta, o investimento do empresariado se resume a ações pulverizadas, de caráter emergencial, de cunho assistencial e visando principalmente à população mais carente.

\section{CONSIDERAÇÕES FINAIS}

A pesquisa Articulação Família e Trabalho foi realizada por meio de 3 procedimentos: a. pesquisa e análise documental - documentos da Organização Internacional do Trabalho - OIT - e da Organização da Nações Unidas - ONU, (convenções/recomendações, relatórios das Conferências Mundiais que tratam da questão feminina etc.); legislação brasileira sobre trabalho (CLT e novas leis em vigor a partir da década de 1990), família (Código civil de 2002) e a própria Constituição de 1988; b. análise sobre o tema dos afazeres domésticos e o do tempo gasto nesses afazeres, por meio de um estudo quantitativo pormenorizado e em profundidade dos quesitos específicos sobre esses temas, na base de dados da PNAD/2002; c. uma análise do tema dos afazeres domésticos, do tempo gasto nesses afazeres, das estratégias de conciliação entre o trabalho e a família, no cotidiano de trabalhadoras urbanas de baixa renda, mediante debates com grupos de mulheres trabalhadoras e mães de filhos pequenos. 
Nesses debates, nos quais foi utilizada a metodologia dos grupos focais, foram discutidas questões como o conceito de trabalho doméstico, a divisão sexual e etária das tarefas domésticas no cotidiano das mulheres, o tempo consumido nas atividades domésticas, as estratégias de conciliação entre o trabalho remunerado e as atividades domésticas e familiares, em grupos de mulheres casadas, vivendo com os companheiros e em grupos de mulheres chefes de família, todas elas de famílias paulistanas de baixa renda (até 5 salários mínimos) e com atividades econômicas diversificadas. Foi discutido também o conhecimento das trabalhadoras a respeito de políticas sociais, públicas e privadas, que favorecem a conciliação entre o trabalho e a família, assim como a expectativa delas em relação a tais políticas. O material recolhido nesses debates alimenta e dá vida aos dados quantitativos os quais, por sua vez, confirmam ou não, para todo o país, o que é dito por elas. Com base nas falas das trabalhadoras foi possível fazer o diagnóstico de alguns dos problemas mais frequentes que afetam seu cotidiano, na interface da família com o trabalho, bem como sugerir propostas para enfrentar tais problemas. Assim, as trabalhadoras mais jovens, que são chefes de família e tem filhos muito pequenos, são as mais sobrecarregadas, porque não contam nem mesmo com o auxílio dos cônjuges em seu cotidiano doméstico e no cuidado com as crianças. Em contrapartida, aparece um discurso, sobretudo entre algumas trabalhadoras que já foram casadas, que esses cônjuges "dão muito trabalho", na forma da alimentação, da limpeza e arrumação da moradia e no cuidado com as roupas. Para todas as que têm filhos muito pequenos, casadas ou chefes de família, as creches são, sem dúvida, a melhor estratégia de cuidado infantil enquanto trabalham. Contudo, relatam tanto qualidades quanto defeitos. Entre os primeiros, a maior disciplina e independência das crianças, entre os defeitos o horário desses estabelecimentos, que não é compatível com o horário comercial e, portanto, do trabalho delas, ocasionando problemas sobretudo no momento da saída, quando elas ainda estão trabalhando. Recorrer à ajuda de parentes (mães, tias, avós), vizinhas ou, eventualmente, a um auxílio remunerado ou à colaboração de colegas de trabalho são as estratégias relatadas.

As trabalhadoras mais velhas, cujos filhos são maiores, descrevem um cotidiano menos pesado, no qual os filhos mais velhos, principalmente as filhas, colaboram, tanto nos afazeres domésticos propriamente ditos, quanto no cuidado com os irmãos menores. As preocupações e os cuidados, entretanto, 
Família e trabalho...

não são poucos. Concentram-se sobretudo na atividade dos filhos quando não estão na escola, razão pela qual sugerem a adoção das seguintes políticas pelos governantes: escolas em tempo integral, com tempo e ajuda para fazer as lições de casa, lazer nas escolas nos finais de semana, para toda a família, portões fechados e segurança em geral nas escolas, educação física no período escolar, evitando uma circulação indesejável das crianças, a qual poderia acarretar o contato com más companhias, drogas e outros problemas. Entre algumas políticas públicas já adotadas, elogiam os Centros de Educação Unificados CEUs - e as políticas de transporte escolar. Em relação ao setor privado, as trabalhadoras apontam a necessidade de que as empresas cumpram com seus direitos legais, como licença maternidade, creche e local para amamentação. Enfatizam também a importância de jornadas de trabalho flexíveis, que thes facilitem a conciliação entre o trabalho e a família. Nem todas as mulheres que participaram dos debates trabalham no setor formal de trabalho, no qual teriam acesso aos direitos trabalhistas. Não foram poucos os relatos daquelas que abriram mão de bons empregos, com todos os direitos assegurados, mas com extensas jornadas, para ficar com os filhos pequenos em casa ou para trabalhar em outra atividade, como autônomas.

O tema das responsabilidades familiares de trabalhadores e trabalhadoras vem ganhando espaço no âmbito internacional, desde a década de 1960 , quando surge, na OIT (1965), a Recomendação I 23 (sobre Mulheres com Responsabilidades Familiares). Na época, o problema da conciliação do trabalho com a família estava fortemente associado ao trabalho feminino remunerado, em franca ascensão. Paralelamente, surgiram movimentos sociais que, ao reivindicar a igualdade entre homens e mulheres, acabaram produzindo, entre outros efeitos, leis e documentos internacionais que apoiam essa perspectiva. Contudo, apesar das responsabilidades familiares ainda serem um encargo majoritariamente feminino, com as mudanças demográficas, econômicas e sociais das últimas décadas, a tendência tem sido a de enxergar a questão como um problema da família e não somente das mulheres. Assim, as políticas públicas de conciliação entre trabalho e família devem levar em consideração não só facilidades familiares que possibilitem às mulheres as mesmas oportunidades de trabalho existentes aos homens, mas também mecanismos de responsabilização masculina nessas tarefas. É importante ressaltar que a Convenção 156, sobre Trabalhadores com Responsabilidades Familiares (OIT, I98I), 
complementada pela Recomendação 123, sobre o Emprego de Mulheres com Responsabilidades Familiares, traz uma importante contribuição ao tema, definindo o conceito de responsabilidades familiares e sugerindo políticas. $\bigcirc$ documento, que entrou em vigor em 1981, entretanto, não foi ratificado pelo Brasil, apesar das mudanças na legislação brasileira como na Constituição de 1988 e no Código Civil de 2002 (Brasil, 1988, Brasil 2002) que garantem a igualdade entre homens e mulheres no interior da família.

\section{REFERÊNCIAS BIBLIOGRÁFICAS}

ABRAMO, L. Questionando um mito: os custos do trabalho de homens e mulheres. Brasília: OIT, 2005

BELLONI, M.-C.; BOULIN, J.-Y. ; JUNTER-LOISEAU. A. Do tempo do trabalho aos tempos da cidade. In: HIRATA, H.; MARUANI, M. As Novas fronteiras da desigualdade: homens e mulheres no mercado de trabalho. São Paulo: Senac, 2003. p. 197-211.

BRASIL. Presidência da República. Lei n. 10.406, de 10 de janeiro de 2002. Disponível em: www.planalto.gov.br/ccivil_03/LEIS/2002/LI 406.htm. Acesso em: mar. 2008.

Constituição da República Federativa do Brasil de 1988. Disponível em: www.planalto.gov,br/ccivil_03/Constituição/Constituição.htm. Acesso em: mar. 2008.

BRUSCHINI, C. Mulher, casa e família: cotidiano nas camadas médias paulistana. São Paulo: Vértice, FCC, 1990.

Trabalho doméstico: inatividade econômica ou trabalho não-remunerado? Revista Brasileira de Estudos de População, São Paulo, v.23, n.2, p.33।-353, jul./dez.2006.

BRUSCHINI, C.; LOMBARDI, M. R. Mulheres e homens no mercado de trabalho brasileiro: um retrato dos anos 1990. In: MARUANI, M.; HIRATA, H. (orgs.) As Novas fronteiras da desigualdade: homens e mulheres no mercado de trabalho. São Paulo: Senac, 2003. p.323-36I.

BRUSCHINI, C.; RIDENTI, S. Trabalho domiciliar masculino. Revista de Estudos Feministas. São Paulo, v.3, n.2, 1995. p.363-392.

CHODOROW, N. The Reprodution of mothering: psychoanalysis and the sociology of gender. Berkeley: University of California Press, 1978.

DEDECCA, C. S. Tempo, trabalho e gênero. In: COSTA, A. A. et al. (orgs.) Reconfiguração das relações de gênero no trabalho. São Paulo: CUT Brasil, 2004. p.21-52. 
Família e trabalho...

FIBGE. IBGE divulga indicadores sociais sobre a mulher. Comunicação Social, 7 mar. 2002 Disponível em: http://www.ibge.gov.br. Acesso em: 26 mar. 2006.

Pesquisa nacional por amostra de domicílios - 1992: notas metodológicas. Rio de Janeiro, 1992.

Pesquisa nacional por amostra de domicílios - 1992: questionário. Rio de Janeiro, 1993.

GATTI, B. A. Grupo focal na pesquisa em ciências sociais e humanas. Brasília: Liber Livro, 2005. (Pesquisa em Educação, 10)

IPEA. A Iniciativa privada e o espírito público: a evolução da ação social das empresas privadas no Brasil. Brasília: Cepal, 2006.

KAPPEL, M. D.; KRAMER, S.; CARVALHO, M. C. Perfil das crianças de 0 a 6 anos que frequentam creches, pré-escolas e escolas: uma análise dos resultados da Pesquisa sobre Padrões de Vida/IBGE. Revista Brasileira de Educação, Campinas, v. I, n. I6, p.35-47, jan./abr. 200 I .

OIT. Employement (women with family responsibilities convention) recommendation: 1965. Disponível em: http://www.ilo.org/llolex/english/recdisp I.htm. Acesso em: mar. 2008.

Workers with family responsibilities convention: 198।. Disponivel em: http:// www.ilo.org/lolex/english/recdispl .htm. Acesso em: mar. 2008.

SORJ, B. Reconciling work and family: issues and policies in Brazil. Geneva: International Labour Office, 2004a. (Conditions of Work and Employment Series, 8)

Trabalho remunerado e trabalho não-remunerado. In: OLIVEIRA, S.; RECAMÁN, M. VENTURI, G. (orgs.) A Mulher brasileira nos espaços público e privado. São Paulo: Fundação Perseu Abramo, 2004. p. I07-I 19.

UNBEHAUM, S. Experiência masculina da paternidade nos anos 1990: estudo de relações de gênero com homens de camadas médias. Dissert. (Mestrado) Departamento de Sociologia, Universidade de São Paulo. São Paulo, 2000.

Recebido em: abril 2008

Aprovado para publicação em: outubro 2008 